\title{
Karo Ethnic Crafts As Teaching Materials Based on Local Content For Junior and Senior High School Students in Medan City
}

\author{
$1^{\text {st }}$ Gamal Kartono ${ }^{1}, 2^{\text {nd }}$ Fuad Erdansyah $^{2}, 3^{\text {rd }}$ Muslim $^{3}, 4^{\text {th }}$ Adek Cerah Kurnia Azis ${ }^{4}$ \\ \{gmalkart@gmail.com ${ }^{1}$, ferdansyah@gmail.com ${ }^{2}$, tanjung.muslim422@gmail.com ${ }^{3}$ \}
}

Department of Fine Arts Faculty of Languages and Arts, Universitas Negeri Medan, Indonesia 1,2,3,4 $^{2}$

\begin{abstract}
The aim of these research are; 1). Producing Karo Tribe Arts and Crafts Teaching Materials as Local Content-Based Teaching Materials for Junior High Schools in North Sumatra issued by ISBN for publishers who are already registered members of the Indonesian Publishers Association (IKAPI); 2). Revealing the validation, practicality, and effectiveness of Karo Tribe Arts and Crafts Teaching Materials for SMP in North Sumatra, in this case the module validation value is $92.12 \%$ with a very valid category, the practicality value of the module by students is at an achievement level of $91.1 \%$ can categorized as very practical, this shows that the module is able to increase user interest in the learning process, and for student activities it is included in the active category because it is in the percentage of $79.37 \%$, and 3). Produce scientific publications in International Proceedings carried out by LPPM Universitas Negeri Medan, namely at the International Conference on Innovation in Education, Science and Culture and scientific publications in the National Accredited Sinta-4 Journal, the Journal of Art Expression Institut Seni Indonesia Padangpanjang. Further researchers are expected to develop character-based modules (soft skills) which are more emphasized on attitudes to increase interest and learning outcomes in the Micro Teaching, Wood Carving Crafts, Ornament, and other Subjects for Students of the Department of Fine Arts, Faculty of Language and Arts, Universitas Negeri Medan.
\end{abstract}

Keywords: karo ethnic crafts, teaching materials.

\section{Introduction}

The implementation of the 2013 curriculum focuses on encouraging students to be better able to observe, ask questions, reason, and communicate (present) what they get or know after receiving learning materials at school. The learning objects in the 2013 curriculum emphasize more on natural phenomena, social phenomena, artistic phenomena, and cultural phenomena. Through this approach, students are expected to have better attitudes, skills, and knowledge competencies. They will be more creative, innovative, and more productive, so that later they can be successful in facing various problems and challenges in the 21 st century, in other words the theme of curriculum development 2013 is to produce Indonesian people who are productive, creative, innovative, and affective through strengthening attitudes, skills, and abilities. and integrated knowledge. The core of the 2013 curriculum is simplification and thematic-integrative efforts. The 2013 curriculum is prepared to produce a generation that is 
ready to face the future. Therefore, the curriculum is structured to anticipate future developments that are more complex and challenging.

Departing from the author's empirical experience from 2015 to 2018 as a Resource Person for 2013 Curriculum Implementation and Teacher Professional Education and Training (PLPG) in the office plus observation of the results of second semester II student internships (Even FY 2018/2019) in schools in the city Data obtained from Medan, that: Teachers do not have books in the form of teaching materials related to Arts and Crafts in the North Sumatra region which consists of eight tribes, Teacher and Student Guidebooks facilitated by the Ministry are still very general in nature, The role of the Subject Teacher Council (MGMP) is not yet maximally and effectively in the difficulties that teachers usually experience in schools when entering teaching materials related to Fine Arts and Crafts in the North Sumatra region. consisting of eight ethnic groups. co-teaching related to the Fine Arts and Arts of North Sumatra which consists of eight tribes, the low knowledge of students about the Fine Arts and Crafts of North Sumatra which consists of eight tribes, will have an impact on students' appreciation of local culture and other cultures, outside their own culture and This will reduce the love for local cultural diversity, love for the homeland which leads to love for the nation's own work with a sense of Nationalism and Cultural Tolerance, and One of the competencies of the XXI Century and new literacy in the Industrial Revolution 4.0. is human literacy related to cross-cultural understanding. Seeing from the conditions mentioned above, this research provides an opportunity for Arts and Crafts teachers from the North Sumatra region to be able to have handbooks related to the eight ethnic groups in North Sumatra. The process of making the book is carried out in stages starting from the Karo ethnic book to other ethnic groups, so that teaching materials from each ethnic group in North Sumatra will be collected.

There are many expert opinions about teaching materials, namely teaching materials are all forms of materials used to assist teachers or other educators in carrying out teaching and learning activities in the classroom, either in the form of written materials such as handouts, books, modules, worksheets. , brochures, leaflets., wallcharts, as well as unwritten materials such as videos/films, VCDs, radio, cassettes, computer-based interactive CDs and the internet. Teaching materials in written form are materials that must be studied by students in the form of students or students as a means to achieve competency standards and basic competencies [1]. Furthermore, which explains about learning media, [2] learning media are everything that can be used to channel messages from sender to recipient, information source recipients of information recipients of information are sources of information so that it can stimulate one's thoughts, feelings, concerns and interests. so that the expected learning process occurs. . Teaching materials are also said to be the most basic important component in the learning system in the classroom, where their presence can be a determinant of the achievement of the learning objectives themselves.

Many models are used in the process of developing teaching materials, one of which is the ADDIE model, which is a model that has the characteristics of a systematic learning design [4]. Based on the description of the opinion above, it can be concluded that teaching materials are a set of tools and materials in the learning process and are closely related to everything that is used as a channel for messages from the sender of the message to the recipient. messages, in the sense that those who act as message senders are educators (teachers, lecturers)., and other types of educators) to students (students, students, and other students) as recipients of messages by carrying out various forms of development ranging from books, modules, worksheets, brochures, videos, VCDs, radios, CDs, and so on. 


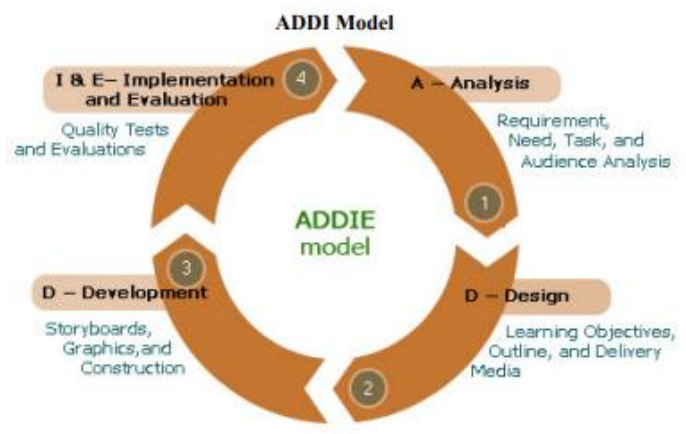

Fig. 1. ADDIE Model.

Based on the description of the opinion above, it can be concluded that teaching materials are a set of tools and materials in the learning process and are closely related to everything that is used as a distributor of messages from the sender of the message to the recipient of the message, in terms of those who act as message senders in the form of educators (teachers, lecturers). , and other types of educators) to students (students, students, and other students) as recipients of the message

Before talking about fine art in particular, there are other things that must be recognized first, namely what art is, art is a process, in general this process consists of several parts, including starting from ideas and ideas, there will be no artwork produced. without any ideas and ideas, this idea becomes the soul of the work we want to make [6]. After understanding what art is in general, then it can be related between Fine Arts and Crafts. Fine arts and crafts are two things that cannot be separated, where the two things will always be related to each other. What is Fine Arts? Fine Art is a branch of art whose work can be enjoyed and felt by the human senses. Even this explanation of Fine Arts can be broader and consists of several types of 2-dimensional and 3-dimensional Fine Arts.

[7] Conrad stated that "Fine Art is art that has quality, expression, and beauty in various ways that exceed its authenticity by grouping objects/subjects against aesthetic criteria". In line with Conrad's opinion above, La Mery, an expert on 2 Dimensional Art from France whose book was translated by Soedarsono, stated that Fine Art is a symbolic vision of expression in higher and more beautiful forms and forms which are neutralized into beautiful forms. as a form of self-expression and emotion [8]. Fine Art as an expression of one's soul which is imagined in a beautiful form that is expressed and can be enjoyed by the public in art performances or exhibitions.

Departing from the opinions of the experts above, it can be concluded that Fine Art is an expression of the soul in the sense of aesthetic value from extraordinary ideas and then expressed or expressed in two-dimensional or three-dimensional forms. Next, talk about Cash on Craft. Crafts are "something related to handmade or activities related to goods produced through hand skills (crafts) with a touch of beauty. Crafts made are usually made of various materials, from these crafts produce decorations or art objects or goods to be used." [10] Then another opinion is that handicrafts produced through hand skills (such as mats, weaving, etc.), simple, usually contains elements of art, can also be interpreted as a small business that is done at home. Meanwhile, handicrafts are activities of making simple items by hand. Handicrafts are works of art made from skilled hands, are also priceless symbols and cultural identities, one example of crafts is songket weaving, where every region in Indonesia have 
their own characteristics. has its own differences regarding crafts, including areas in North Sumatra [12] [13]. Based on the explanation of the definition of craft above, it can be concluded that, craft is the result of the creation of skilled human hands made with hand skills with the help of tools and supporting materials so as to produce a work of beautiful value that becomes a symbol and cultural characteristic of a person. every area.

The Karo tribe is one of the largest ethnic groups in Indonesia, based on the census of the Central Statistics Agency in 2010. This name is a collective theme to identify several ethnic groups who live and come from the West Coast and East Coast in North Sumatra Province. The ethnic groups categorized as Karo are Angkola, Karo, Mandailing, Pakpak/Dairi, Simalungun, and Toba. The Karo are a group of tribes that inhabit most of North Sumatra [14]. However, people often think that the mention of Karo is only for the Toba tribe, even though Karo is not only for the Toba tribe. Currently, the Karo people generally adhere to Protestant Christianity, Catholic Christianity, and Islam. The diversity of religions and ethnicities of the Karo people, as well as their culture, in North Sumatra makes this province a special attraction for tourists. Each tribe has different traditions and adds to the richness of culture in this Sumatran land, such as the four uniqueness of several local tribes in North Sumatra that do not exist in other areas. Here's the description: 1). Mangokkal Holi is a hereditary tradition of the Karo people, namely Mangokkal Holi means taking the bones of their ancestors from the grave. Then placed in a coffin and placed in a special monument building to store the bones. This tradition requires a large amount of money because in addition to slaughtering livestock, the event is held for several days. All ethnic Karo carry out the Toba ethnic tradition and Simalungun calls it Mangokkal Holi, in Karo ethnic it is called Tampakken Tulan, and Pakpak knows it as Mengkurak Tulan tradition, [15]. The Karo tribe is also the name of a district in North Sumatra, namely Tanah Karo, and this tribe also has its own language, namely Karo or often North Sumatran people with the term Cakap Karo [16].

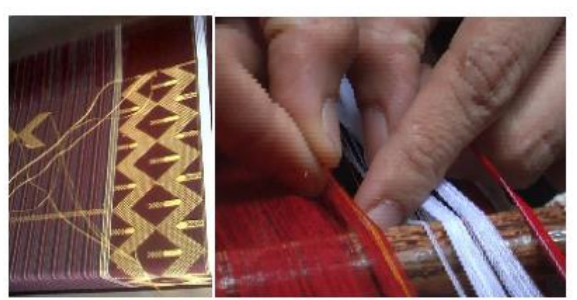

Fig. 2. Traditional Karo Uis Nipes Fabric Craft and Karo Uis Making [17].

Based on the purpose of this study, namely to produce Teaching Materials for Karo Tribe Arts and Crafts as Teaching Materials Based on Local Content for Junior High Schools in North Sumatra that are valid, practical, and effective. Based on all that, this research is included in the type of development research. This research will be conducted using a 4D model (four-D model). The model used in this study is a 4D model (four-D model). [18] According to Thiangarajan the development of the four-D model consists of 4 (four) stages: 1). Definition (define); 2). Design (design); 3). Development (develop); and 4). Spread (dessiminate). This research has only reached the development stage, namely stage 3 (three), while dissemination is not carried out. This teaching material was developed using the four D (4-D) model, but in this study only 3 stages were carried out, namely definition, design, and development, while the dissemination stage was not carried out. due to time and cost constraints. 


\section{Method}

Based on the purpose of this research, which is to produce teaching materials or onlinebased learning modules (e-books) and prints with ISBN that are valid, practical, and effective, therefore, this research is included in the type of development research. This research will be conducted using 4D models (four-D models). [18] According to Thiangarajan the development of the four-D model consists of 4 (four) stages: 1). Definition (define), 2). Design (design), 3). Development (develop), and 4). Spread (dessiminate). This research only reached the development stage, namely stage 3 (three), while the disseminate was not carried out, citing time and cost constraints of course.The research location is focused on the Department of Fine Arts, Faculty of Language and Arts Unimed, which is the object of this research are Fine Arts students who are taking Research Methodology Courses, there are classes A, B, C, and D, each class can be averaged 26 students. The research was conducted in the Even Semester of the Academic Year 2020/2021 on the class schedule of the Students of the Department of Fine Arts in the Decorative Variety Course.

\section{Results and Discussion}

\subsection{Validation}

The validation results after being revised, then each validator gives a score, after each validator gives a score then data analysis is carried out. The results of data analysis can be seen in table 1 below:

Table 1. Validator Assessment Results.

\begin{tabular}{ccc}
\hline Variable & Achievement (\%) & Category \\
\hline Module Contents & $92 \%$ & Very Valid \\
\hline Construction & $90.5 \%$ & Very Valid \\
\hline Language & $90.5 \%$ & Very Valid \\
\hline Module Display & $95.5 \%$ & Very Valid \\
\hline Average & $\mathbf{9 2 . 1 2 \%}$ & Very Valid \\
\hline
\end{tabular}

The results of the analysis of the validator's assessment score above which consist of 4 (four) variables explain that, 1). The content of the module is at the achievement of a score of $92 \%$ with a very valid category, 2). Construction is at the achievement of $90.5 \%$ included in the very valid category, 3). The language variable of $90.5 \%$ is in the very valid category, and 4). The module display is $95.5 \%$ which is included in the very valid category too. Based on the achievement of the scores above, it can be taken the average of the four variables, $92.12 \%$ of the average results are included in the very valid category as well. The comparison of the degree of achievement of the module validation results on each variable that has been assessed by the validator can be seen in Figure 3 below: 


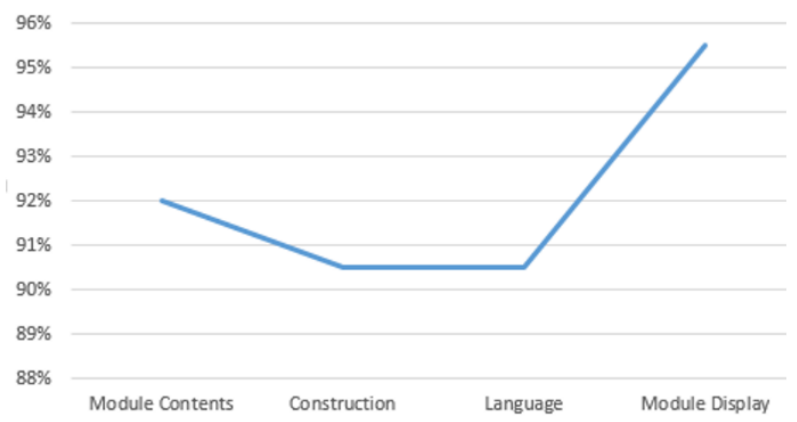

Fig. 3. Validator Assessment Results.

\subsection{Module Practicality}

This practicality was assessed by students of the Fine Arts Education Study Program, Department of Fine Arts, Faculty of Language and Arts, Universitas Negeri Medan, where students were also the object of testing. After the assessment is carried out, then data analysis is carried out. The results of data analysis can be seen in table 2 below:

Table 2. Student Practical Results.

\begin{tabular}{ccc}
\hline Variable & Achievement (\%) & Category \\
\hline Convenience for users & $88 \%$ & Practical \\
\hline Usability & $95 \%$ & Very Practical \\
\hline Time effectiveness & $90.5 \%$ & Very Practical \\
\hline Average & $\mathbf{9 1 . 1 \%}$ & Very practical \\
\hline
\end{tabular}

The results of the analysis of the assessment data of students of the Fine Arts Education Study Program, Department of Fine Arts, Faculty of Language and Arts, Universitas Negeri Medan which is also the object of testing this module, there are 3 (three) variables, namely 1). Ease for Users (Learnability) with the achievement of $88 \%$ felt in the practical category, 2). Efficiency is at $95 \%$ in the very practical category, and 3). Time Effectiveness is $90.5 \%$, this shows that it is in the very practical category. The average value of practicality by students with an achievement level of $91.1 \%$, so from these results it can be said that the module is in the very practical category. More details about the practical achievement of the module by students can be seen in Figure 4 below: 


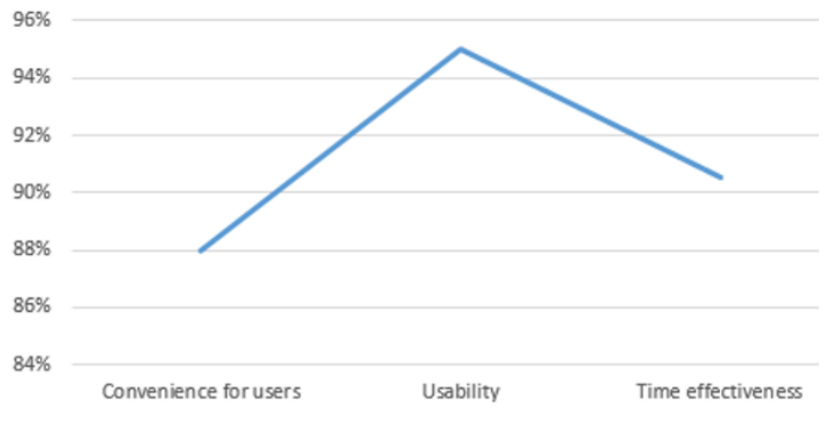

Fig. 4. Student Practical Results.

\subsection{Module Effectiveness}

Activities categorized by observers are as follows: a). Read modules and do exercises; B). Giving questions to the lecturer concerned during the teaching and learning process; C). Provide answers to all questions given by the lecturer concerned; and D). Collect assignments given by the lecturer. The first activity is reading the module and doing the practice questions, the presentation of student activities reading the module and doing the exercises from the first meeting to the second meeting is $100 \%, 100 \%, 100 \%$, and $100 \%$. On average $100 \%$ entered into the active category once. In the second activity, students ask questions to the lecturer while participating in the teaching and learning process. The percentages of activity from the first meeting to the fourth meeting are as follows: $65.71 \%, 57.62 \%, 50 \%$, and $55.24 \%$, with an average of $57.14 \%$, so they are included in the fairly active category. Based on the data above, students who asked the lecturers at the four meetings decreased in the second and third meetings, but increased in the fourth meeting. It can be said that learning by using modules can improve student learning outcomes.

In the third activity, students answered questions from lecturers and questions from colleagues. The percentages from the four meetings are as follows: $59.52 \%, 57.62 \%, 61.43 \%$, and $62.86 \%$, so that an average of $60.35 \%$ can be obtained. This can be categorized as an active student. Based on the percentage data above, it can be said that students experienced an increase from the first meeting to the fourth meeting in answering questions from lecturers and colleagues. The fourth activity completes the tasks given by the lecturer. All students collect their assignments from the first meeting to the second meeting where the percentage of each meeting is as follows: $100 \%, 100 \%, 100 \%$, and $100 \%$, with an average student activity of $100 \%$, it can be categorized as a very active student. The tasks given must be completed by each individual, so that each student has responsibility for the tasks given by the lecturer. The average student activity above from each category can be seen in general in table 3 below:

Table 3. Module Effectiveness Results.

\begin{tabular}{ccc}
\hline Student Activity Category & Achievement (\%) & Category \\
\hline $\begin{array}{c}\text { Reading modules and doing } \\
\text { exercises }\end{array}$ & $100 \%$ & Very Active \\
\hline Questions to the lecturer & $57.14 \%$ & Active Enough \\
\hline Provide answers to all questions & $60.35 \%$ & Active \\
\hline
\end{tabular}




\begin{tabular}{ccc}
\hline posed by lecturers and colleagues & & \\
\hline $\begin{array}{c}\text { Collect assignments given by the } \\
\text { lecturer }\end{array}$ & $100 \%$ & Very Active \\
\hline Overall Average & $\mathbf{7 9 . 3 7 \%}$ & Active \\
\hline
\end{tabular}

Based on the results of the analysis of student activities during the learning process with an achievement level of $79.37 \%$ in the category of active students. To see a comparison of the things above can be seen in Figure 5 As follows:

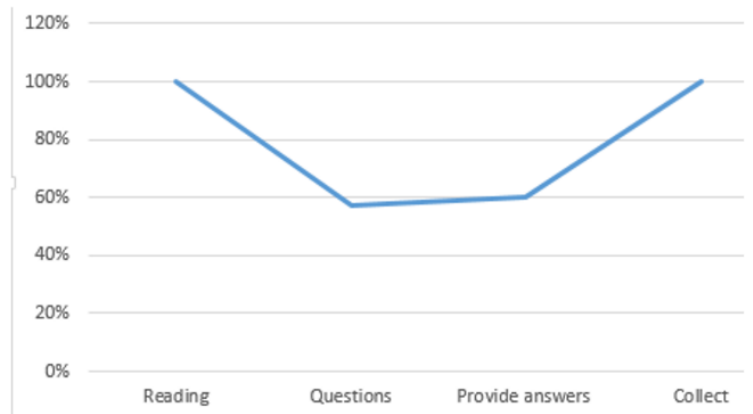

Fig. 5. Module Effectiveness Results.

\section{Conclusion}

Based on the description of the results of the validator's assessment, student practicality, and student activity achievements can be described as follows: 1). Module Content, Construction, Language, and Module Display are $92.12 \%$, this indicates that the module is in the very valid category. The description of the contents of the module is arranged systematically, this makes it easier for users to understand the module. The module is formulated in a learning unit that begins with singing the material and evaluating it. The presentation of the module is in accordance with the student's ability level. According to the Ministry of National Education [19], a module is said to be good and easy for students to understand if the material is in a complete unit according to the ability of its users (Self Contained).

The ease for users (Learnability) of the module, namely the lecturer as a guide in the learning process with a value of $88.66 \%$ is in the practical category for users. Where the module has instructions, language that is in accordance with student characteristics, can be used individually, and the exercises contained in the module can help lecturers in providing direction to students to understand concepts. The purpose of the module design is to make it easier for lecturers to guide and direct students in the learning process. The usefulness of the module for students (Efficiency) with a score of $99.68 \%$ is in the very practical category. Modules can assist students in explaining concepts. In addition, it is also expected to help lecturers direct students in the learning process. "One of the objectives of the module is to clarify and simplify the presentation of messages so that they are not too verbal [19]. Practicality and effectiveness of time are in the very practical category with an achievement value of $90 \%$. The modules developed are practically used by lecturers to guide students in the 
learning process. Lecturers can use minimal time with maximum learning outcomes. According to the Ministry of National Education, a good module can overcome the limitations of time, space, and students' senses in the learning process [19].

The results of the student learning evaluation can be declared as passing as many as 20 . The percentage of students who pass is $100 \%$. The purpose of the evaluation is to find out whether the students being taught already have the competencies that have been determined so that they are worthy of being given further learning materials. The practicality of the module proves that, 20 students who use the module in the learning process, $100 \%$ of students are declared complete. [20] Practicality refers to the condition of the learning modules developed that are easy to use by users (teachers, students, and students) so that the learning carried out is meaningful, interesting, fun and beneficial for students' lives, and can increase their creativity in learning. Furthermore, based on the observations observed by one observer, generally students are active in the learning process. This shows that the module is very practical and effective to use in the learning process and can increase students' interest in the teaching and learning process. The Karo Tribe Arts and Crafts Module has been produced as a local content-based teaching material for secondary schools in North Sumatra, to improve students' knowledge, skills, interests, and learning outcomes during the teaching and learning process. The value of the validity of the module is at $92.12 \%$ in the very valid category. The practical value of the module by students is at the level of achievement of $91.1 \%$ which can be categorized as very practical and able to increase user interest in the learning process, and for student activities it is included in the active category because it is in the percentage of $79.37 \%$. This shows that the module has a positive effect on students' knowledge of Karo Ethnic Arts and Crafts in North Sumatra. Further researchers are expected to develop character-based modules (soft skills) that focus more on attitudes to increase interest and learning outcomes in the Micro Learning process, Wood Carving Crafts, and other courses for students of the Department of Fine Arts, Faculty of Language and Arts, Universitas Negeri Medan.

Acknowledgments. The author would like to thank the Dean of the Faculty of Language and Arts and the Head of the Department of Fine Arts who have given permission to the author to carry out this Faculty research, then to all students of the Department of Fine Arts, Faculty of Language and Arts, Unimed who have been involved in the implementation of this research, and in particular to the Institute for Research and Community Service, Universitas Negeri Medan regarding the BOPTN-2021 funding for the implementation of this research, so that this research goes well.

\section{References}

[1] Depdiknas. Pedoman Memilih dan Meyusun Bahan Ajar. Jakarta: Depdiknas; 2006b.

[2] Sadiman AS, et al. Seri Pustaka Teknologi Pendidikan No.6 Media Pendidikan Pengertian, Pengembangan, dan Pemanfaatannya. Jakarta: CV Rajawali; 1986.

[3] Nurzaelani MM, Kasman R, Achyanadia S. Pengembangan Bahan Ajar Integrasi Nasional Berbasis Mobile. JTP-J Tek Pend. 2018; 20(3):264-279.

[4] Tegeh IM, Kirna IM. Pengembangan Bahan Ajar Metode Penelitian Pendidikan dengan ADDIE Model. J Ika. 2013; 11(1):12-26.

[5] Muruganantham G. Developing of E-content package by using ADDIE model. Int J Appl Res. 2015; 1(3):52-54.

[6] Felix J. Pengertian Seni Sebagai Pengantar Kuliah Sejarah Seni Rupa. Humaniora. 2012; 3(2):614621.

[7] Kottak CP. Cultural Anthropology. Pennsylvania State University: McGraw-Hill; 2000. 
[8] Mery L. Komposisi Tari, Elemen-elemen Dasar: Diterjemahkan dari Buku Dance Composition: The Basic Elements oleh Soedarsono. Jakarta: Akademi Seni Tari Indonesia; 1975.

[9] Art H. Letters from Art: Art Hawkins Standing Tall in the Shadow of Aldo Leopold. North Central Wisconsin: Orange Hat Publishing; 2019.

[10] Kontan. Kerajinan. Available from: https://www.kontan.co.id/topik/kerajinan [Accessed 14 ${ }^{\text {th }}$ May 2020].

[11] Mahzuni D, Mumuh MZ, Ayu S. Pengembangan Kerajinan Tangan Berbasis Kearifan Budaya di Pakenjeng Kabupaten Garut. Dharmakarya: J Aplikas Ipteks untuk Masyarakat. 2017; 6(2):101105.

[12] Muhajirin. Dasar-Dasar Kerajinan. Available from: http://staffnew.uny.ac.id/upload/132102200/pendidikan/DASAR-DASAR+KERAJINAN.pdf [Accessed 14 ${ }^{\text {th }}$ May 2020].

[13] Viatra AW, Triyanto S. Seni Kerajinan Songket Kampoeng Tenundi Indralaya, Palembang. Ekspresi Seni: J Ilmu Pengetahuan Dan Karya Seni. 2014; 16(2):168-183.

[14] Wikipedia. Suku Batak. Available from: https://id.wikipedia.org/wiki/Suku_Batak [Accessed 14th May 2020].

[15] Andriansyah A. 4 Tradisi Unik ini Hanya Bisa Kamu Temukan di Sumatera Utara. Available from: https://www.brilio.net/jalan-jalan/4-tradisi-unik-ini-hanya-bisa-kamu-temukan-di-sumatera-utara-170103b.html [Accessed 15 $5^{\text {th }}$ May 2020].

[16] Wesnina W. Perspektif Generasi Muda Suku Karo Terhadap Kain Tradisional Suku Karo: Sebuah Analisis. J Penelitian dan Pengembangan Sains dan Humaniora. 2020; 4(1):10-18.

[17] Thiagarajan S, et al. Instructional Development for Training Teachers of Exceptional Children. Washington DC: National Center for Improvement Educational System; 1974.

[18] Depdiknas. Pengembangan Bahan Ajar Sosialisasi KTSP 2008. Available from: http://dc218.4shared.com/download/vj4M9KIo/5_PE [Accessed $29^{\text {th }}$ January 2012].

[19] Alfiriani A, Hutabri E. Kepraktisan dan keefektifan modul pembelajaran bilingual berbasis komputer. Jurnal Kependidikan. 2017; 1(1):12-13. 